\title{
Global conservation status assessment of the threatened aquatic plant genus Baldellia (Alismataceae): challenges and limitations
}

\author{
Gregor Kozlowski · Stéphanie Rion • André Python • \\ Sébastien Riedo
}

Received: 4 June 2008 / Accepted: 1 February 2009 / Published online: 14 February 2009

(C) Springer Science+Business Media B.V. 2009

\begin{abstract}
In this study, the aquatic monocot Baldellia (Alismataceae) is used as a model for evaluating the general hindrances and shortfalls in the global conservation status assessment of a threatened taxon. Our study clearly shows that Linnean shortfalls (uncertainty in the number of species and taxonomy) and the Wallacean shortfall (fragmentary knowledge regarding distribution) form the basis for all other hindrances. We demonstrate that even in Europe, which has traditionally been very well investigated, between 60 and $75 \%$ of regions or countries possess no detailed distribution maps and/or data banks for Baldellia spp. Furthermore, between 50 and $60 \%$ of regions do not have any published red list category. Thus, only general conclusions concerning the global conservation status of the three Baldellia taxa are possible - a global assessment of conservation status for B. ranunculoides subsp. repens is nearly impossible. Baldellia ranunculoides s.str. shows a strong decline in practically all regions of its natural range, and thus it is probably the most threatened species in the genus. Baldellia alpestris is the least threatened species in the genus, even though it is a narrow endemic. Our case study clearly shows the need for reinforced coordination of research and conservation activities as well as an urgent need for data accessibility regarding taxonomic, chorological and conservation studies of endangered species.
\end{abstract}

Keywords Aquatic macrophyte - Conservation priority · Wallacean shortfall · Linnean shortfall $\cdot$ Red list

Electronic supplementary material The online version of this article (doi:10.1007/s10531-009-9589-3) contains supplementary material, which is available to authorized users.

G. Kozlowski $(\bowtie) \cdot$ S. Rion

Department of Biology and Botanical Garden, University of Fribourg, Ch. du Musée 10, 1700 Fribourg, Switzerland

e-mail: gregor.kozlowski@unifr.ch

S. Rion $\cdot$ A. Python $\cdot$ S. Riedo

Department of Geosciences, Geography, University of Fribourg, Ch. du Musée 4,

1700 Fribourg, Switzerland 


\section{Introduction}

The current extinction crisis and the extent of anthropogenic alteration of natural habitats have reached alarming proportions (Brown and Lomolino 1998; Rodrigues 2006). An acceleration of biodiversity deterioration is expected for the future (Foley et al. 2005). Faced with low resource availability for conservation activities and with growing management costs for endangered species and habitats, priority setting has become one of the most widely discussed topics in conservation biology (Master 1991; Wilcove and Chen 1998; Marris 2007b). Therefore, many governments and organizations are planning to create new priority lists of endangered species while taking their global conservation status into consideration (Welk 2001; Eggenberg and Landolt 2006). Such global estimation is not simple, and scientists as well as private and governmental agencies lack essential knowledge of target species (Rodrigues 2006; Kozlowski 2008).

Potential hindrances to global assessment of priority list candidates have been divided into eight categories (Kozlowski 2008): (1) the extreme heterogeneity of existing data; (2) the restricted availability of relevant data and lack of information exchange between scientists and conservationists; (3) the uncertainty in species number and taxonomic division of the given taxon (Linnean shortfall); (4) the fragmentary knowledge of distributions (Wallacean shortfall); (5) incomplete or erroneous red-listing across the entire distribution of a given taxon; (6) the lack of homogenous and reliable population trend data; (7) the lack of exhaustive information on observed and potential threats; and finally (8) the incomplete general biological knowledge of a given taxon (e.g., its reproduction biology, genetic diversity, dispersal parameters, etc.). It has been demonstrated that Linnean and Wallacean shortfalls are among the most serious problems in modern conservation biology and biogeography (Brown and Lomolino 1998; Lomolino and Heaney 2004), and that the majority of deficits in knowledge during any global conservation status assessment results from these two shortfalls (Whittaker et al. 2005; Bini et al. 2006; Kozlowski 2008).

The main goal of our study was to highlight the extent of our knowledge deficits and to test all shortfall categories mentioned above using a focal taxonomic group. We have used the aquatic plant genus Baldellia as a model taxon. This work was done in parallel with our recent review on B. ranunculoides (Kozlowski et al. 2008), which is, therefore, not included in our analysis. Baldellia is one of several small genera in the monocot family Alismataceae. There are generally only two recognized species in the genus: $B$. ranunculoides (i.e., B. ranunculoides subsp. ranunculoides or B. ranunculoides s.str.), native to Europe and the Mediterranean, and B. alpestris, endemic to the mountains of northern Portugal and northwestern Spain (Lawalrée 1959; Vasconçellos 1970; Cook 1983; Moreno Saiz and Sainz Ollero 1992). However, numerous studies recognize a third taxon (with more of an Atlantic biogeographic range) that has been treated as either B. ranunculoides subsp. repens or as $B$. repens. All species of Baldellia are aquatic herbs. They are very weak competitors and can only grow in habitats within a discrete range of disturbance linked to particular water levels and low nutrient availability. They are typical plants of open shorelines and long-standing gaps in oligotrophic lakes (Cook 1983; Vuille 1988; Preston and Croft 2001). In most regions, they are the characteristic species of so-called Littorelletean and Isoetid communities (classes Littorelletea uniflorae and Isoëto-Nanojuncetea, respectively) (Casper and Krausch 1980; Pott 1995; Schubert et al. 1995).

The genus Baldellia is particularly suitable for such an evaluation because: (1) in many regions it is an emblematic taxon and candidate for many conservation priority lists; (2) it is an exclusively aquatic taxon growing in habitats that are especially sensitive to anthropogenic alterations; (3) it comprises only three taxa; (4) it contains taxa for which there are 
dissimilar degrees of biological knowledge; and (5) its distribution covers countries and regions with differing levels of conservation activities and biodiversity exploration. The general conclusions of our work will hopefully stimulate the development of new strategies and organizational structure for better coordination of species conservation policy and conservation biology studies.

\section{Materials and methods}

The available information on all three species of Baldellia was collected through: (1) recent and older literature screening; (2) an internet search of online data banks and websites on local floras and local or regional conservation activities; and (3) contacts with national and/or local experts. We consulted more than 3,000 publications or electronic sources and contacted more than 100 experts. Our recent review on B. ranunculoides (Kozlowski et al. 2008), which formed the basis for part of this survey, is not considered in this analysis. The red list categories discussed in our study are those of the International Union for Conservation of Nature (IUCN 2001). For countries and/or islands with a published red list category for Baldellia taxa, the category was taken without any adaptation. However, some of these existing categories may have been assessed using different previous sets of IUCN criteria which were valid at the time of their publication. For regions with exact distributional data, the loss of historical range could be calculated using the coefficient of decline (CD, sensu Delvosalle and Vanhecke 1982). The coefficient was calculated as follows: $\mathrm{CD}_{(y)}=100-(a / b \times 100)$, where $a$ is the number of populations observed before year $y$ in a given area; $b$ is the number of populations observed after year $y$ in a given area; and $y$ is the dividing year for the calculated periods. The coefficient is given as a percentage and represents the proportion of populations that disappeared before the dividing year.

In order to expand the available information and to compare literature data with the current situation, an in situ survey on a large scale was carried out in habitats of all three species of Baldellia across their global range. The survey was conducted during 2 years (2006-2007) at the height of the growing season. Altogether, 53 sites containing Baldellia populations from ten countries in Europe and North Africa were sampled: 22 of $B$. ranunculoides s.str., 18 of $B$. ranunculoides subsp. repens and 13 of B. alpestris. Species of Baldellia were identified according to the detailed keys of Triest and Vuille (1991) and Jones (2006). In each Baldellia site visited, we carefully surveyed water-body margins as well as the surrounding area in order to assess observed and potential threats, geographical coordinates, altitude and habitat type. The threats described in the literature, as well as those observed during the field survey, were recorded using a standardized form and classified into several categories (see Tables 1 and Appendix S1 in Supplementary Material).

\section{Results}

\section{Distribution}

Baldellia ranunculoides s.str. has been reported from 28 countries and on six large Mediterranean and Atlantic islands (34 regions total, Fig. 1; Appendix S1). The newly discovered, naturalized populations outside of Europe (e.g., North America, New Zealand) have not been taken into consideration. For B. ranunculoides s.str., maps are available for 


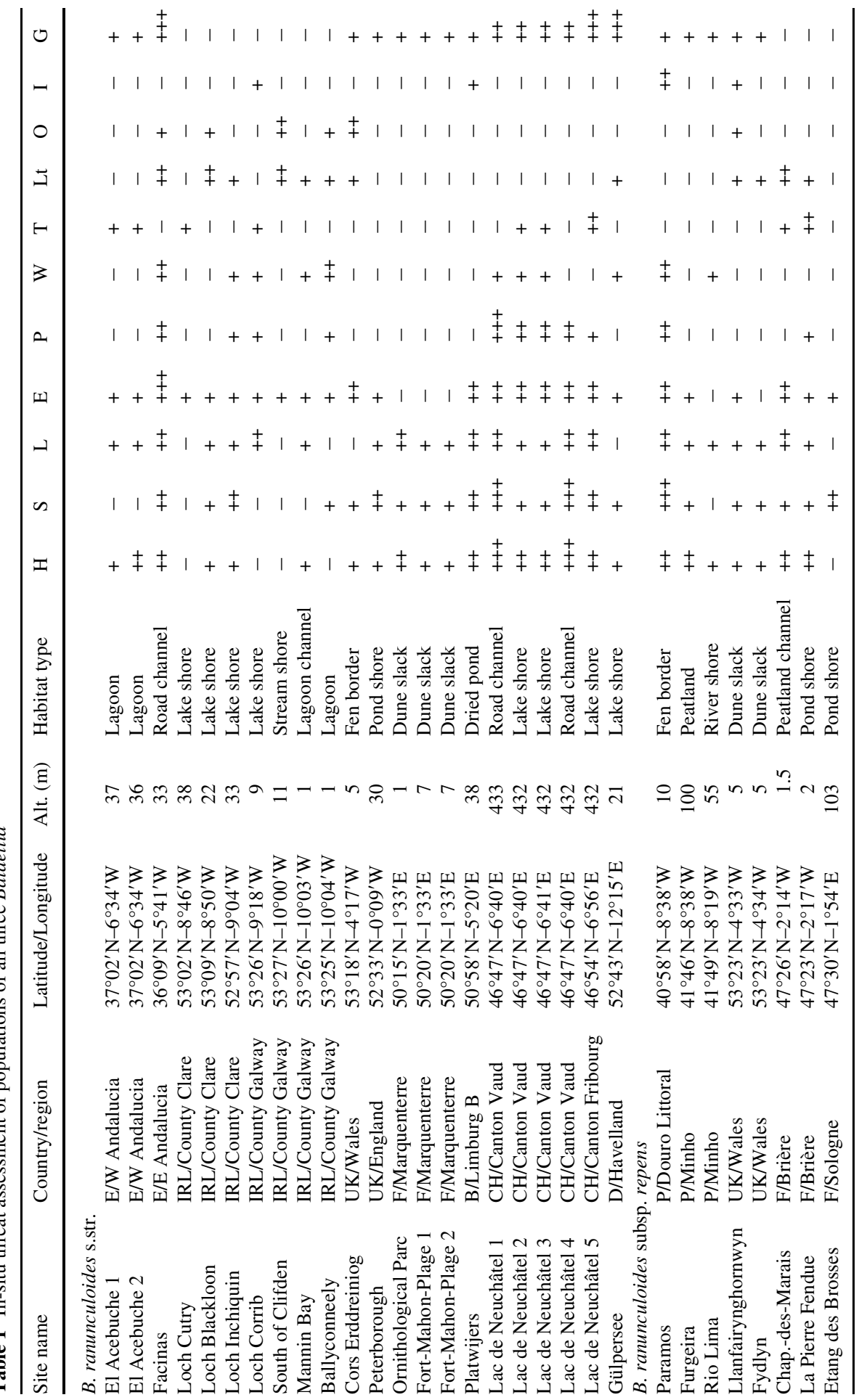




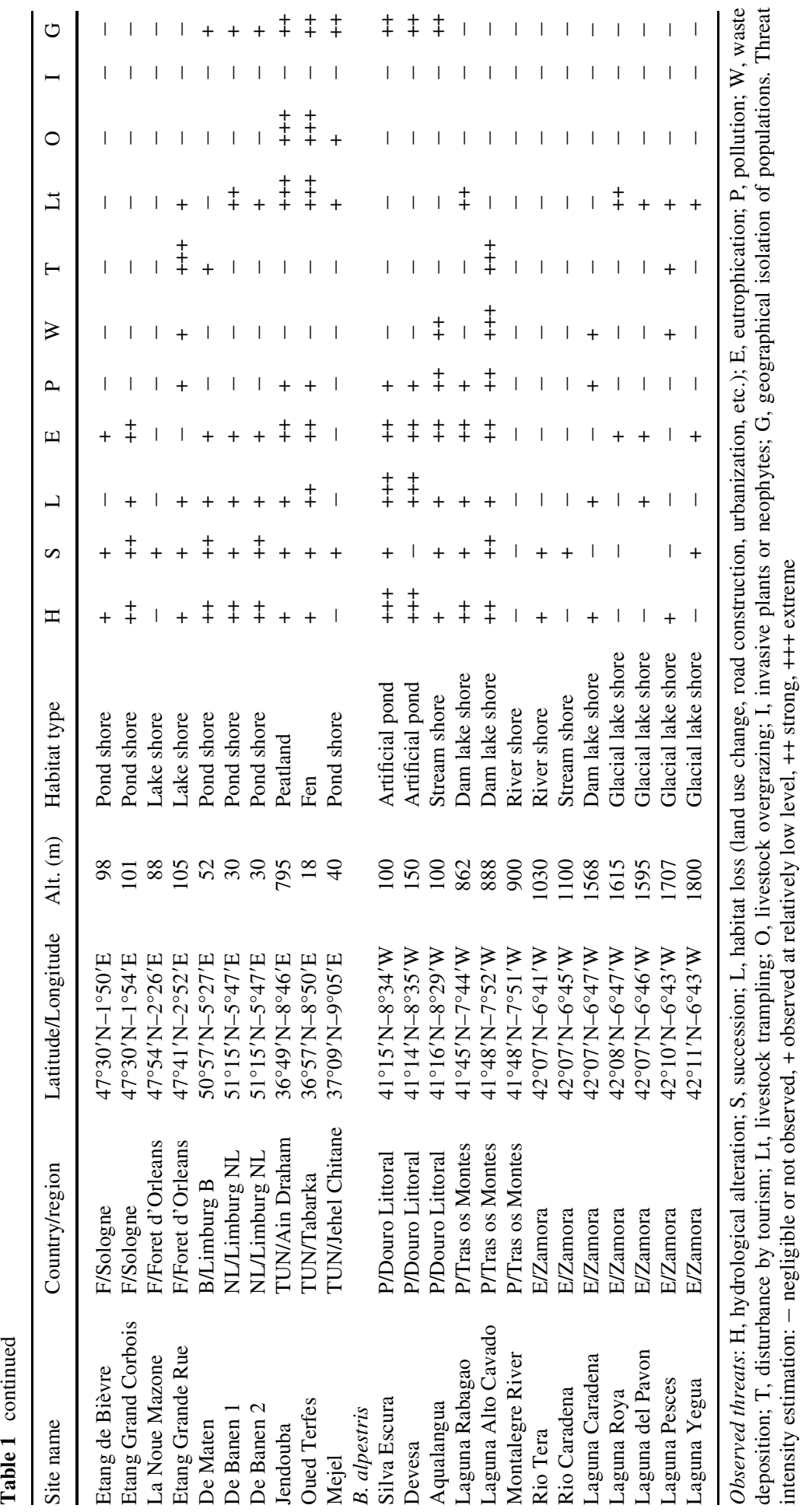




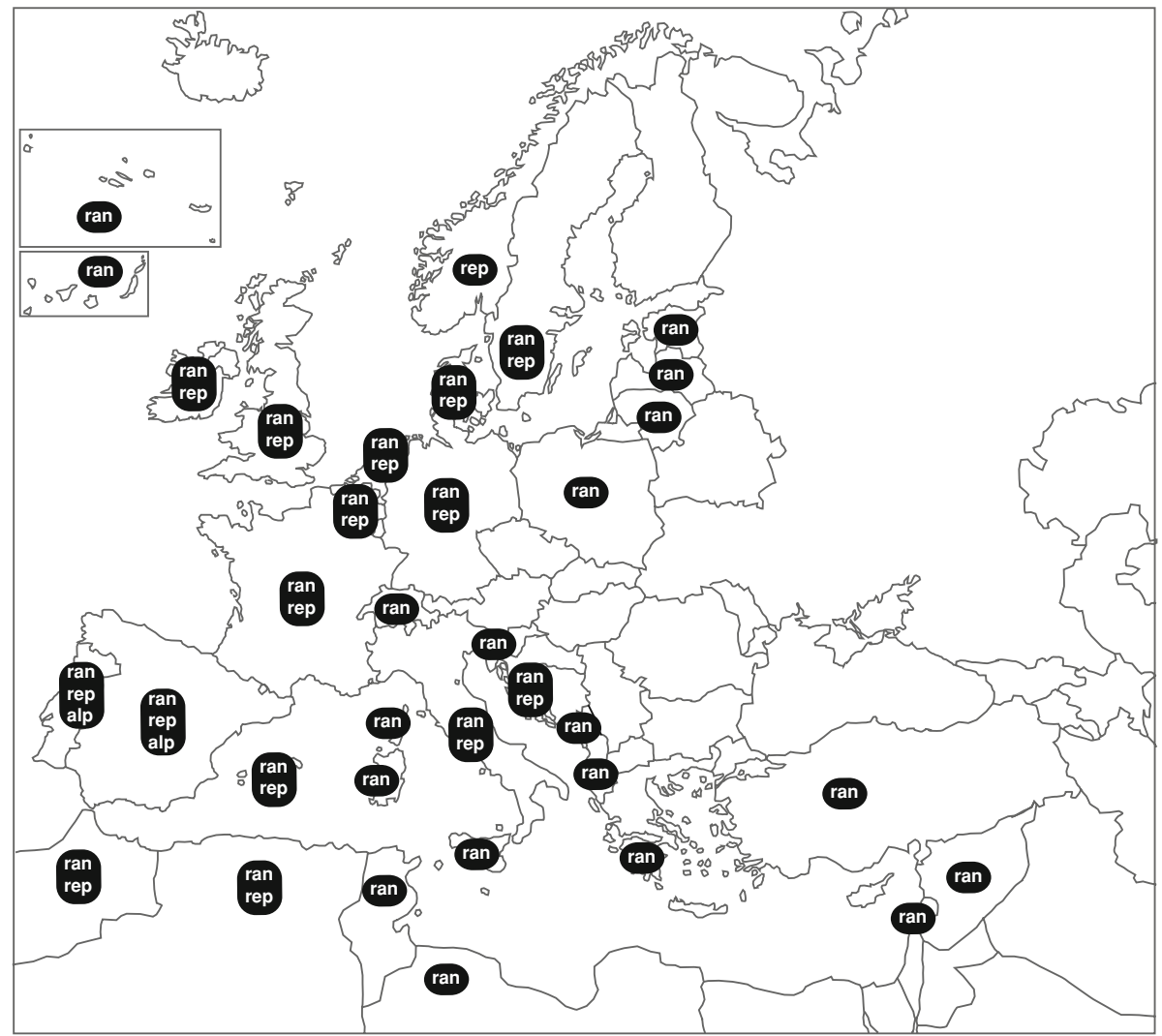

Fig. 1 Study area-schematic representation of the global historical and present distribution of all Baldellia taxa as described in the literature. Abbreviations: ran, B. ranunculoides s.str.; rep, B. ranunculoides subsp. repens; alp, B. alpestris (for more details and references see Appendices S1 and S3)

20 regions (59\% of all regions with $B$. ranunculoides s.str.). The quality, accessibility and methodology used for their creation, however, vary significantly. Only 14 regions (41\%) have detailed distribution maps, whereas six regions possess only schematic ones that are not suitable for conservation purposes (Fig. 2a). Thus, more than half of all the regions possess very fragmentary mapping or no data at all on the past and present distribution of B. ranunculoides s.str.

The exact distribution of $B$. ranunculoides subsp. repens is still not known. The subspecies has been documented in 16 regions (Fig. 1; Appendix S1). In Norway, it is the only native member of the genus (i.e., no B. ranunculoides s.str. occurs there). Distribution maps are extremely rare; only Scandinavian countries and Belgium possess detailed maps, and the map for France is very schematic (Fig. 2b). Thus, 75\% of all regions with $B$. ranunculoides subsp. repens have no precise distributional data on this subspecies' distribution and abundance. Additionally, during our field survey (Table 1), we detected populations of B. ranunculoides subsp. repens in Tunisia for the first time. This has not previously been documented in the literature, and was also unknown to experts we consulted. 

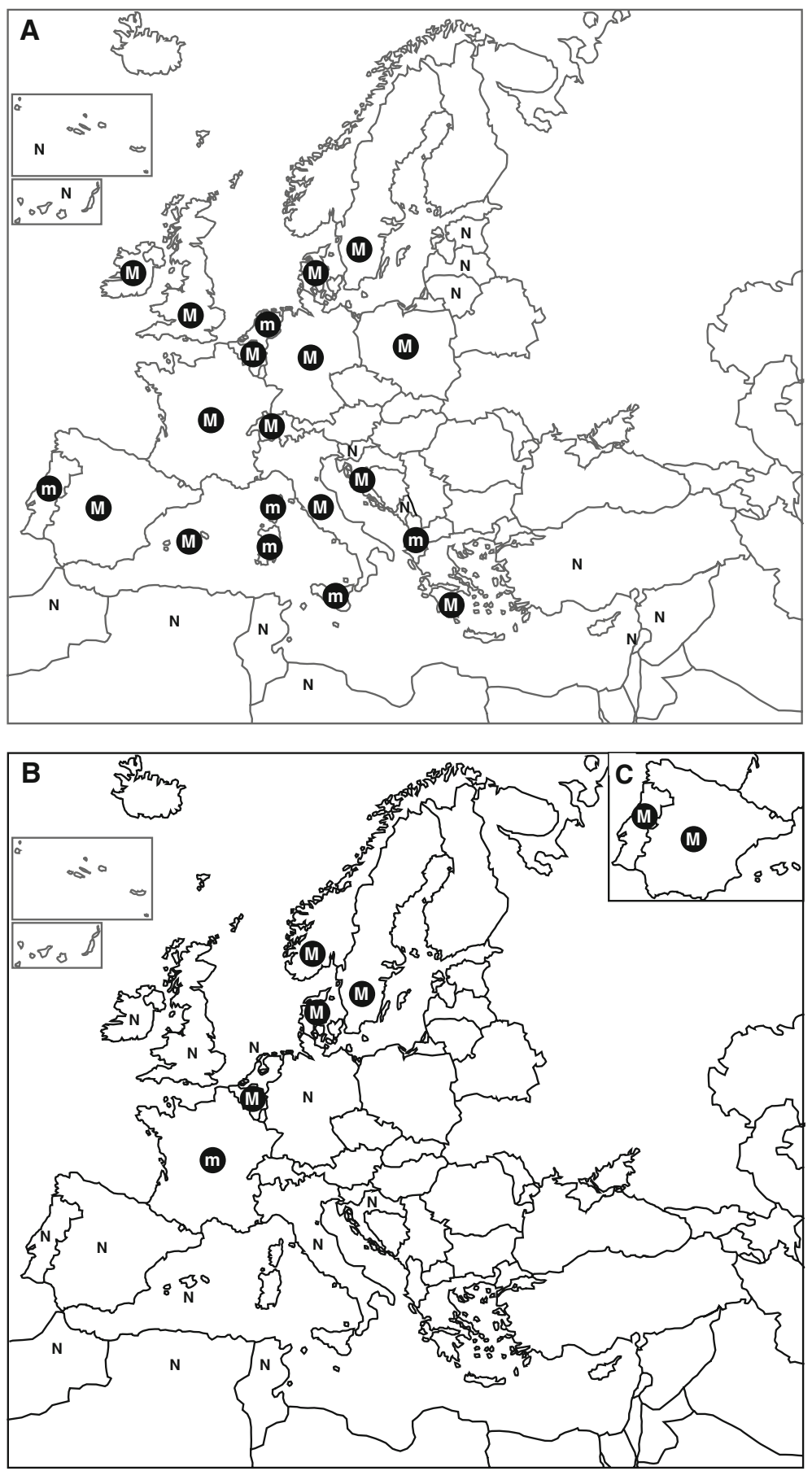

Fig. 2 Wallacean shortfall expressed with the availability of distribution maps. M, detailed distribution map available; $\mathrm{m}$, schematic distribution map available; $\mathrm{N}$, map not existing. a $B$. ranunculoides $\mathrm{s}$.str.; b B. ranunculoides subsp. repens; c B. alpestris (for more details and references see Appendices S1 and S3) 
Baldellia alpestris occurs only on the Iberian Peninsula in northern and northwestern Spain, and northern Portugal. Relatively good maps as well as herbaria and literature records are available for both countries (Fig. 2c; Appendix S1).

\section{Red list categories}

For Baldellia ranunculoides s.str., red list categories were found for national and/or local red lists for 18 regions (i.e., 53\% of all countries and islands with B. ranunculoides s.str., Fig. 3a). For 16 regions the conservation status has not yet been estimated (NE). For B. ranunculoides subsp. repens, there are only six countries with published red list categories (Fig. 3b). In the rest of its distribution (60\% of regions with B. ranunculoides subsp. repens), no red list category was published (NE). Baldellia alpestris is not considered to be threatened (LC) in Spain or Portugal (Fig. 3c).

\section{Population trends}

The information available was very incomplete (Fig. 4; Appendix S1). For B. ranunculoides s.str., it was only possible to deduce population trends for 15 regions $(53.5 \%$ of all regions where $B$. ranunculoides s.str. still exists; Fig. 4a). A strong decline has been described in all of the regions (besides Greece). Information on population trends of B. ranunculoides subsp. repens is much scarcer (60\% of regions have no data at all) and conclusions were only possible for six regions (Fig. 4b). With the exception of Norway (population trends stable at very low levels), a very strong decline was observed in five countries: Belgium, France, the Netherlands, Sweden and Germany, where the taxon is probably extinct. Populations of B. alpestris, especially those in mountainous regions of northern Portugal and Spain, seem to be stable (Fig. 4c). Calculating the coefficient of decline (CD) was only possible for nine countries and only for B. ranunculoides s.l. (B. ranunculoides s.str. plus $B$. ranunuloides subsp. repens). The $\mathrm{CD}$ ranges from $\mathrm{CD}_{(1950)}$ $22.91 \%$ for Italy to $\mathrm{CD}_{(1998)} 92.16 \%$ for Switzerland. The calculation of $\mathrm{CD}$ with recent distribution data (last 10 years) was possible only for Switzerland and the eastern federal states in Germany (Appendix S1).

\section{Threats}

For 10 regions (28\% of all 35 regions containing species of Baldellia), no data exist whatsoever (Appendix S1). Land use change was the most often described threat (mentioned in $46 \%$ of all regions), followed by hydrological changes (40\%) and eutrophication $(34 \%)$. An important threat, pollution, was also often mentioned (23\%) as well as was geographic isolation $(26 \%)$. Additionally, more threats have been described in other regions: succession (14\%), livestock overgrazing (14\%) and trampling (11\%). The acidification of lakes and tourism development were mentioned in only two and three regions, respectively. Table 1 shows data collected during the field survey in 53 sites for all three species of Baldellia. We used the same threat categories as in Appendix S1 for the literature/experts data. We detected that strong threats also occur in countries where Baldellia is not officially threatened (e.g., in Ireland, Spain, Portugal). The majority of Baldellia sites we visited displayed more than six threat categories (out of 11 surveyed). Sites with only one or two observed threats were extremely rare. These were mainly isolated or protected areas without any human activity in the vicinity (Table 1). 

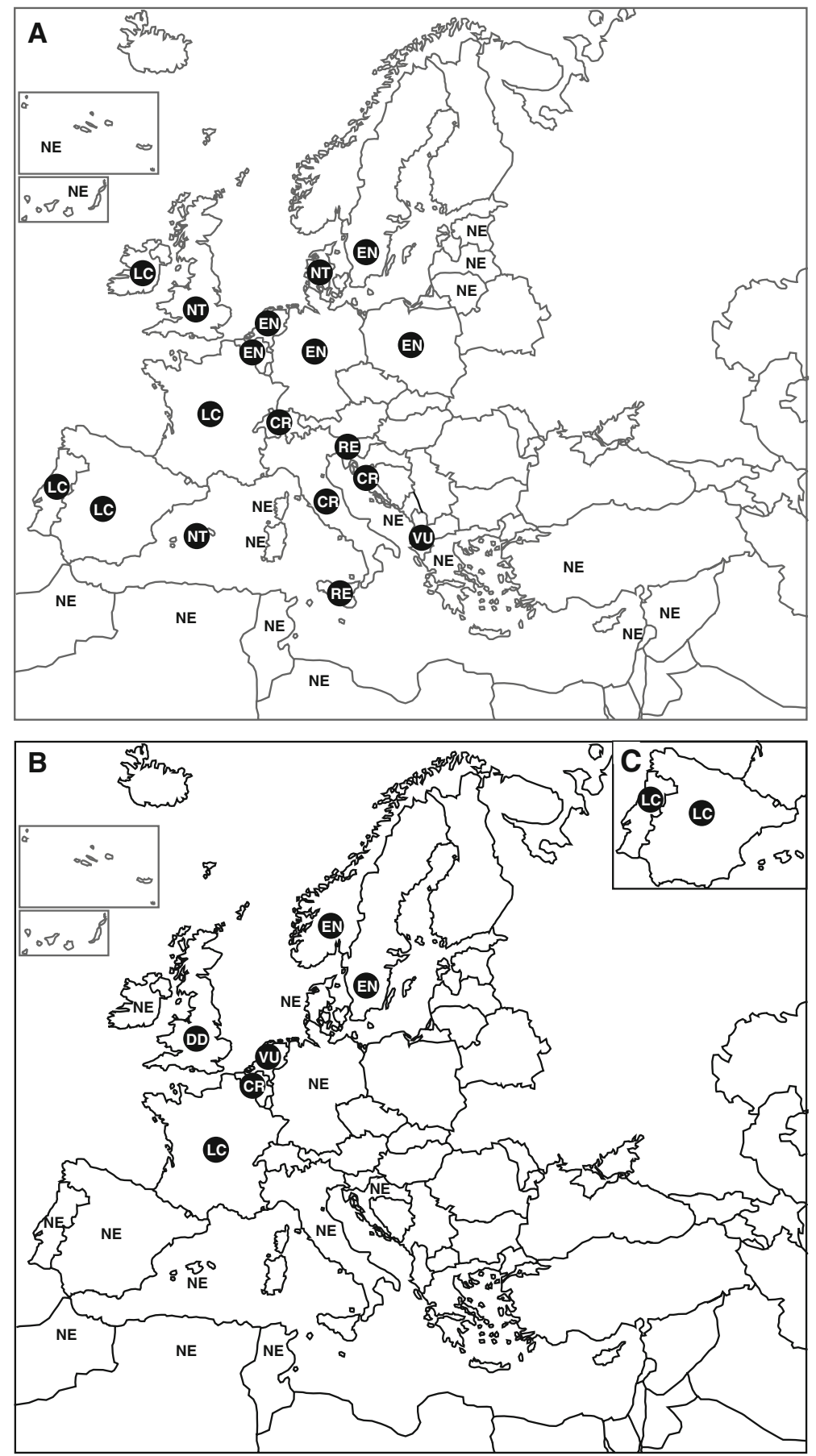

Fig. 3 Red-listing expressed with IUCN red list categories. a B. ranunculoides s.str.; b $B$. ranunculoides subsp. repens; $\mathbf{c}$ B. alpestris. Circles categories published in official national or regional red lists; $N E$ red list category not evaluated (for more details and references see Appendices S1 and S3) 

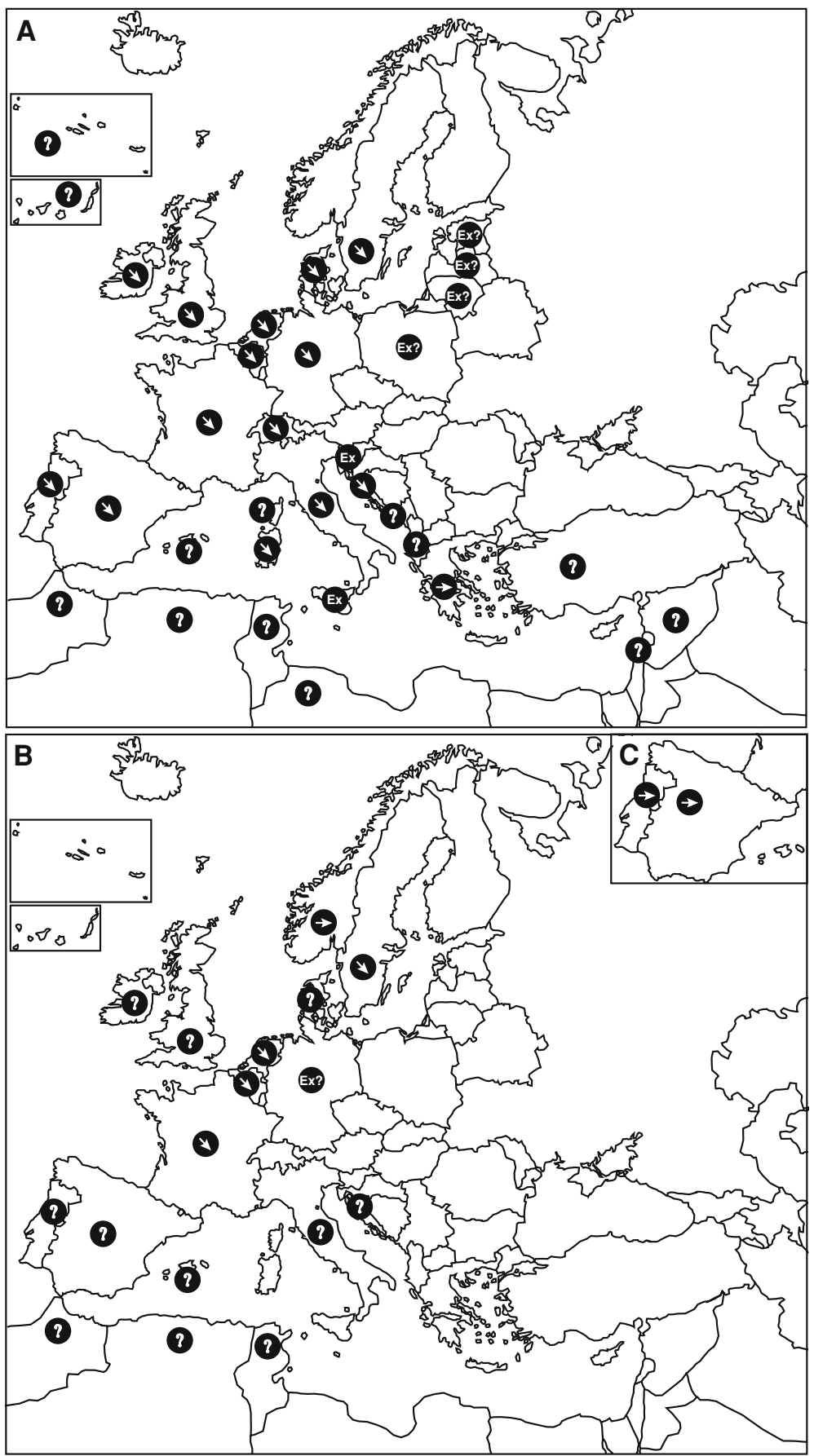

Fig. 4 Population trend knowledge shortfall. Arrow down population number declining; Horizontal arrow populations stable; $E x$ regional extinction; $E x$ ? regionally probably extinct; ? population trend data not available. a $B$. ranunculoides s.str.; b $B$. ranunculoides subsp. repens; $\mathbf{c} B$. alpestris (for more details and references see Appendices S1 and S3) 
General biological knowledge

Figure 5 shows the current status of general biological knowledge on the genus Baldellia, expressed as the number of published and available sources (publications in scientific journals and book chapters). The highest number of publications concerned taxonomy, morphology, anatomy, habitat requirements and communities (see also Appendix S2). The percentage of papers, however, devoted exclusively to one of the species of Baldellia and to a given subject was extremely low. For many biological knowledge categories, there are only general publications with merely indirect and/or scant information and conclusions on Baldellia. There are, for example, no phytosociological studies focused entirely on Baldellia, although data on communities containing Baldellia were found in at least 40 scientific works. According to our survey, there are no more than ten scientific publications devoted exclusively to species of Baldellia published during the last 250 years (Appendix S2). Thus, until now, the majority of biological knowledge on Baldellia has been poorly explored. This is especially the case for herbivory, population structure, dispersal, phenology, biochemistry, physiology, genetic diversity and mycorrhizae.

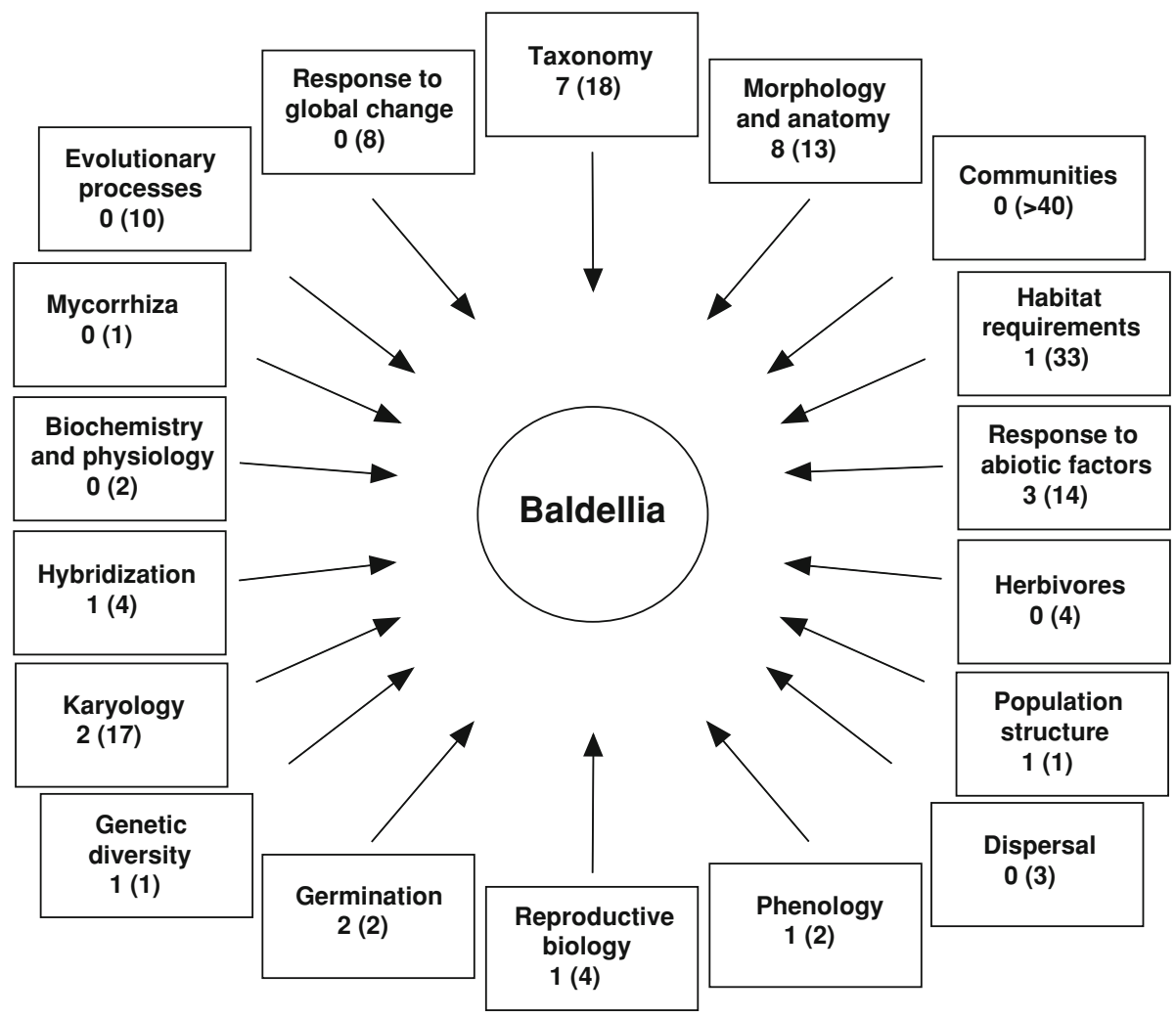

Fig. 5 State of general biological knowledge on the genus Baldellia expressed as number of available peerreviewed publications and book chapters. First number publications devoted almost exclusively to one Baldellia taxon and to a given category of the biological knowledge. Numbers in brackets other publications, giving only partially and indirectly information on one of Baldellia taxa. For references see Appendices S2 and S3 


\section{Discussion}

Data heterogeneity and availability shortfalls

One of the first obstacles faced by any scientist or conservationist who wishes to assess a given taxon globally and gather as much information on it as possible is the extreme heterogeneity and poor availability of existing data (Kozlowski 2008). The majority of relevant data are hidden in local journals (often unavailable electronically), in local databases (often accessible only with permission and/or not published on the internet), in unpublished theses, reports, action plans, field surveys, etc., and are often written in many different languages (Terschuren 1999; Glisson 2004). The data collection for our study is a perfect illustration of such extreme heterogeneity (see sources in Appendix S1 and full reference list in Appendix S3). Thus, our study clearly demonstrates that it is impossible to do any global conservation status assessment emphasizing only refereed literature, the accepted standard in science. Unpublished data are, therefore, extremely important. Such data should be, however, applied while considering limitations of a variety of methods used to collect them as well as the diversity of persons delivering the information. In order to eliminate or at least minimize these first two hindrances, more efforts should be undertaken to improve coordination of ongoing conservation activities and information exchange among different conservation actors (conservation biologists, administration units, politicians, local conservation agents, etc.).

\section{Linnean shortfall}

The Linnean shortfall refers to our extremely limited knowledge of the overall number of taxa on our planet. The term was first proposed by Brown and Lomolino (1998). It is surprising that at the beginning of the twentyfirst century, even in intensively studied regions and in relatively well-known groups of organisms, the Linnean shortfall is still an important and real deficiency (Marris 2007a). This is difficult to understand, given the growing awareness of the importance of biodiversity for natural and human-made ecosystems.

The genus Baldellia is an excellent example of a group with an unclear taxonomy. In addition to the two recognized species in the genus ( $B$. ranunculoides and $B$. alpestris), a third taxon (that has been treated as both $B$. ranunculoides subsp. repens and $B$. repens) still needs appropriate taxonomic recognition. The situation is confusing: in the literature from northern Europe as well as in many publications from the Benelux countries, the taxon is treated as a separate species, B. repens (Lawalrée 1959; Cools 1989; Lindblad and Ståhl 1990; Ingelög et al. 1991; Aronsson 1999; Lid and Lid 2005). This is, however, not the case in central and southern Europe or in North Africa (Casper and Krausch 1980; Vuille 1988), where it is treated as B. ranunculoides subsp. repens. The confusion about the number of Baldellia species, and especially regarding the status of B. ranunculoides subsp. repens, has hindered correct conservation decisions. Similar hindrances have already been described in numerous studies and assessments across many other organisms. The closely related genus Damasonium provides an example of this situation. For a long time it was not clear if there are globally three or five distinct species (Tutin 1980; Rich and NichollsVuille 2001). Any proper conservation measures are only possible if all valid taxa are recognized and well described in the general and regional literature. The present decline of the study of taxonomy in many universities aggravates the Linnean shortfall. However, it is almost naïve to expect that taxonomists will ever agree on how many species there are in certain genera. 


\section{Wallacean shortfall}

This shortfall refers to our inadequate knowledge of the distribution of a given taxon (at all levels: global, regional and local). The name comes from A. R. Wallace who was one of the founders of biogeography and a bird distribution specialist. Although the term was coined only recently by Lomolino and Heaney (2004), the problem is not new. Cook (1983), in his exhaustive work on European aquatic plant species, argued that "one must have information about the local distribution of a species before one can set priorities in conservation measures." Detailed species range maps are, therefore, the basis of any conservation effort. Whittaker et al. (2005) clearly demonstrated that this deficit is not only typical of poorly studied organisms but also, for example, of vascular plants on continents thought to be very well explored (e.g., Europe).

Baldellia is once again a perfect example of the Wallacean shortfall. Poor knowledge of distribution is still an important hindrance to a majority of countries and regions across the range of the genus. More than $60 \%$ of countries or regions possess no detailed distribution maps and/or data banks for $B$. ranunculoides s.str.; the corresponding number for B. ranunculoides subsp. repens is about $70 \%$. Particularly incomplete and outdated are distribution data from North Africa and the Middle East. One of the best solutions would be to visit and screen as much herbaria as possible. Some new discoveries in the eastern Mediterranean (e.g., Montenegro, Greece) and our discovery of B. ranunculoides subsp. repens in Tunisia (Table 1) clearly demonstrate the extent of the Wallacean shortfall of threatened vascular plants in Europe and adjacent regions.

\section{Red-listing shortfall}

In many countries, the World Conservation Union red lists (IUCN 2001) are the most popular conservational tools for designating conservation priorities of endangered organisms (www.redlist.org). Despite their limitations (Quayle and Ramsay 2005), red lists are practically the only internationally comparable conservation status indicators. However, limited time and funding result in red lists that are incomplete or give wrong information (Mrosovsky 1997, 2004). There are two areas for concern regarding listing. On one hand, a fear is that a given taxon needs a much higher red list category than it was given. On the other hand, it is important to avoid the so-called "Romeo error" (Collar 1998), i.e., giving up on a species that is not yet extinct. The "red-listing shortfall" refers not only to a theoretical, but also to a very prosaic problem: many countries and even whole continents do not have any listing of threatened species. Additionally, even in countries with very ambitious red list projects, for many taxa the category DD (Data Deficiency) has to be used (Good et al. 2006). The relatively well-studied amphibians are given as an example: in the ongoing global assessment (www.globalamphibians.org) it was not possible to assign any red list category to $60 \%$ of amphibian taxa. Whatever the red-listing method used in the near future, the basis of the problem remains the same: without substantial funding for exhaustive field surveys, the appropriate red-listing will remain a mere hope (Mrosovsky 2004).

More than $60 \%$ of regions do not have any published red list category for $B$. ranunculoides subsp. repens; for B. ranunculoides s.str. the number is about $50 \%$ (Fig. 3). As for the Wallacean shortfall, the biggest problem is the nonexistence of an exhaustive red-listing of vascular plants in North Africa and Middle East. Another problem exists in countries where the species probably disappeared and new red lists no longer treat it (e.g., Baltic countries) or in regions where the species was recently re-discovered and has not yet been evaluated (e.g., Montenegro, Greece and Turkey). Additionally, the analyses in Table 1 and 
Appendix S1 suggest that the red list categories are underestimated in many western European countries. This is clearly the case for France, Portugal, Spain and the UK (and probably for Ireland), where a strong decline could be demonstrated and numerous threats have been observed in our field survey. This extremely poor red-listing in European countries can be additionally demonstrated by status assessments published online by Plantlife (www.plantlife.org.uk). For Ranunculus ophioglossifolius, for example, only $20 \%$ of countries where the species occurs published any red list category. For Damasonium alisma, the number is only $17 \%$.

\section{Population trend knowledge shortfall}

Knowledge of population trends is one of the most important elements in the evaluation of real extinction risk because they show population size and/or population number and whether they are increasing, decreasing or stable over time (Schemske et al. 1994). Species whose populations are decreasing dramatically will need immediate action and thus should be put at the top of the priority list (Welk 2001). Up to now, however, such detailed demographic analysis has only been studied for a very small portion of taxa, especially at the global scale. Moreover, in order to know the population trend of a given taxon, we not only need precise indications on the number and size of its populations but also data for several points in time.

The information on population trends of Baldellia taxa was very imprecise and came from various sources with differing methodologies and subjective estimations by the authors and experts consulted. For ca. $30 \%$ of regions there were no data available at all. Although the average value of coefficient of decline (65\%, see Appendix S1) clearly showed a strong decline tendency, such a mathematical calculation is very problematic and gives mitigated results. The calculation was possible only for about $20 \%$ of all the regions and only for B. ranunculoides s.l. Additionally, the dividing dates range from the 1930s to the late 1990s. The inaccessibility of raw, local distribution data makes such a calculation at the local and global level impossible. Furthermore, as explained in Rich and Karran (2006), such methods are very dubious, as the ratio of old to new records depends not only on decline but also on relative sampling intensity. The same problem has been described for some very well studied organisms such as Cypripedium calceolus in Europe. The decline for this species could be calculated for only $35 \%$ of surveyed countries (Terschuren 1999).

\section{Knowledge of threats shortfall}

In order to protect efficiently any taxon, one must know the exact reason for its decline. Thus, this knowledge shortfall could significantly hinder the global conservation status assessment. For species of Baldellia, the main described and observed threats were: land use change, hydrological alterations, eutrophication, succession, pollution and geographic isolation. Our field survey (Table 1), however, gives much more detail than data from the literature (Appendix S1) and suggests that in some countries, the conservation status is estimated too optimistically (e.g., in Portugal and Ireland). In all visited sites, an accumulation of several threat categories was observed. The populations thriving in ditches (road channels) and those growing in large lakes surrounded by dense human settlements with strong touristic activities (e.g., in Lac de Neuchâtel in Switzerland) seem to be the most affected by human activities. Populations growing in protected areas such as lagoons in nature reserves along Atlantic coast appear less threatened. Baldellia ranunculoides subsp. repens 
grows in ponds and wetlands that experience less anthropogenic pressures. Today, in many European countries, such habitats are under protection. Thus, hydrological alteration, land-use changes and eutrophication are less accentuated when compared to those of $B$. ranunculoides s.str. The sites containing $B$. alpestris can be divided into two types: (1) lowland sites with heavy anthropogenic pressures and numerous severe threats, and (2) highland rivers and glacial lakes with low anthropogenic influences. The lowland populations, growing in ancient and now mainly abandoned village ponds and basins are among the most threatened of the whole genus. Baldellia alpestris, being an endemic of northern Portugal and northwest Spain, has no more than 15-20 such highly endangered occurrences. In contrast, populations from montane regions are probably the least threatened habitats of the whole genus. A mixture of many threats typical for fragile aquatic habitats is, therefore, playing a very important role in the strong decline of Baldellia across Europe (Casper and Krausch 1980; Preston and Croft 2001). This differentiation was only detected due to our intensive field survey, and it shows the limits of published information.

\section{General biological knowledge shortfall}

The inadequate general biological knowledge (other than distribution, taxonomy and sensibility to anthropogenic stress) has an enormous influence on the global conservation status of any assessed taxon. Scientific literature pertaining specifically to the genus Baldellia is extremely limited and information is often simplified or even omitted completely (Fig. 5; Appendix S2). The level of biological knowledge is not always best measured by the number of publications. A single large, high quality study might provide more knowledge than many small observations. Nevertheless, in comparison with many other taxonomic groups, the genus Baldellia is probably on the better side of the knowledge gradient: there are about ten scientific publications and book chapters devoted almost exclusively to this genus. There are, for example, some historical but still very informative and exhaustive scientific works of Glück $(1905,1906)$ on morphological plasticity of $B$. ranunculoides s.str. and $B$. ranunculoides subsp. repens. More recent publications are the work of Lawalrée (1959) on B. ranunculoides subsp. repens; Vuille (1988) on reproductive biology for all three Baldellia; Lindblad and Ståhl $(1989,1990)$ on the distribution and ecology of B. ranunculoides subsp. repens in Scandinavia; Triest and Vuille (1991) on genetic diversity and hybridization, and the publication of Jones (2006) on B. ranunculoides subsp. repens in Great Britain. Additionally, very informative data on B. ranunculoides s.str. and B. ranunculoides subsp. repens can be found in the general works on aquatic macrophytes of Casper and Krausch (1980) as well as of Preston and Croft (2001). All other information has to be extracted from publications devoted only indirectly to one of the species of Baldellia. Publications devoted almost entirely to $B$. alpestris are even rarer. Although suspected to be a distinct entity in the nineteenth century (Cosson 1864), this endemic was described as a separate species only recently by Vasconçellos (1970). Generally, the most thoroughly studied aspects of the biology of Baldellia are its reproductive biology, morphology and anatomy. All other subjects are insufficiently studied and need much more investigation. There are, for example, almost no scientific reports or data on dispersal and herbivory. The complex questions of evolutionary processes in this genus and of the potential response of Baldellia species to elements of global change also need further studies (for more details on existing literature see Kozlowski et al. 2008). 
Conservation status estimation

Hindered by severe knowledge shortfalls described above, we are able to draw only some general conclusions concerning the global conservation status of the three taxa of Baldellia. B. ranunculoides s.str. shows a strong decline in practically all regions of its natural range. The taxon grows in water-bodies that are affected by strong anthropogenic pressures. The habitat needs of this species are in evident conflict with human activities such as tourism, urbanization, intensive agriculture, etc. Thus, it is probably the most threatened taxon of the genus. The last region to contain numerous populations and high abundance of this taxon, and thus with high international responsibility, is Ireland. In France, Portugal, Spain and the UK, the conservation status is clearly underestimated. In all other countries, active conservation actions must be undertaken. In Africa and the Near East, new field surveys are highly recommended.

The global assessment of conservation status for B. ranunculoides subsp. repens is practically impossible. The scarce data indicate, however, that the taxon is strongly regressing in central and northern Europe. Therefore, we expect the same tendency in all other countries. The main area with numerous, sometimes still highly vital populations of $B$. ranunculoides subsp. repens exists only in central France that has, therefore, a great international responsibility. For all other countries, new field surveys and urgent conservation actions are recommended. This poorly studied taxon also needs intensive ecological and taxonomic studies.

Baldellia alpestris, although a narrow endemic, is the least threatened species of the genus. A majority of populations grow at altitudes between 800 and 2,000 m a. s. 1. in glacial lakes, along mountainous rivers and streams with relatively weak anthropogenic pressure. For all lowland occurrences, in contrast, rapid conservation actions are needed. Spain and Portugal both equally share an international responsibility for preserving this endemic taxon.

\section{General conclusions}

Our results clearly demonstrate that the global conservation status assessment of any taxon is an extremely complex, time-consuming and laborious task. The commonly accepted IUCN red-listing is particularly dissatisfying. We need either considerable improvements of red-listing methodology or invention of completely new conservation status indices that take into account our ignorance concerning certain endangered taxa (Mrosovsky 1997, 2004). Recent efforts at improving the methods of assessment (e.g., "barometers of biodiversity", Butchart et al. 2004) can be applied only for well-studied vertebrate groups such as birds (Rodrigues 2006).

The Linnean and Wallacean shortfalls lay the foundation of all hindrances in such assessments. Without exact taxonomic and chorological data, governments and non-governmental organizations will simply not be able to know what to protect or where to protect it. Additionally, all hindrances described above are strongly interdependent: the population trend and knowledge threat shortages are, for example, responsible for the red-listing shortfall but concurrently result from a Wallacean shortfall.

Much more support has to be given to developing countries in order to improve their knowledge of local biodiversity and biogeography. For European conservation efforts, the data from Mediterranean countries of northern Africa and the Near East are of great importance because these regions constitute a biogeographical unit with Europe. Thus, the lack of 
recent surveys and modern floras almost completely block a precise estimation of the conservation status of many organisms in Europe. One solution would be that leading universities in Europe could take a patronage of one specific region in North Africa/Near East and stimulate, support and coordinate the chorological, taxonomic and conservation studies and efforts with local universities.

Generally, new strategies and methods of data collection, field surveying and information exchange must be developed, for example:

1. creation of international chorological databanks

2. development of multilateral mapping and research programs

3. obligation of nature conservation administrations to create internationally networked databanks

4. obligation of nature conservation administrations and research groups to publish all relevant conservation data on endangered taxa in an online and freely accessible format

5. organization of international field expeditions in regions with poor biodiversity exploration

6. organization of regular local and international conservation meetings

All these efforts and results should be used to create a continuously updated online conservation forum: one known/described taxon with one web-page, where all actors (e.g., conservationists, conservation biologists, taxonomists, scientific journals, scientific libraries, etc.) should be encouraged to allocate all relevant data they possess on a given taxon.

Acknowledgments We would like to thank Benoît Clement and Susanne Bollinger from the Botanical Garden of the University of Fribourg (Switzerland) for their assistance during manuscript preparation. We are also indebted to Antony Buchala, University of Fribourg, for English improvement as well as to the Franklinia Foundation for its engagement and valuable support of field work. Further, we thank following local experts (alphabetical order): Paulo Alves, University of Porto, Portugal; Svein Baatvik, Directorat for Nature Management, Trondheim, Norway; Ramon Casimiro-Soriguer, Dep. Biologia Vegetal y Ecologia, Universidad de Sevilla, Spain; Kristijan Civic, State Institute for Nature Protection, Croatia; Christian Clerc, GEG ChampPittet, Switzerland; Antonio Crespi, Botanic Garden, University of Tras-os-Montes e Alto Douro, Vila Real, Portugal; Mohamed Fennane, Dépt. de Botanique et d'écologie végétale, University of Rabat, Morocco; Abdelkrim Hacène, Dept. de Botanique, Institut National Agronomique, University of Alger, Algeria; Andrew R. Jones, Countryside Council for Wales, UK; Mitja Kaligaric, Katedra za geobotaniko, Slovenia; Mart Külvik, Head of Research Centre. Environmental Protection Institute, Estonia; Leht Malle, The Estonian naturalist society, Estonia; Viesturus Melecis, Institute of Biology, University of Latvia; David Draper Munt, Museum Nacional de História Natural, Universidade de Lisboa, Portugual; Baudewijn Odé, Director of Stichting Foron, Leiden, the Netherlands; Francis Olivereau, Diréction régionale de l'environnement de la region Centre, France; Salvatore Pasta, Tutela delle specie vegetali prioritarie delle Isole Eolie, Sicily; Henrik Ærenlund Pedersen, University of Copenhagen, Denmark; Oscar Sánchez Pedraja, Grupo botànico cantàbrico, Cantabria, Spain; Uwe Raabe, Naturschutzamt Nordrhein-Westfalen, Deutschland; Jacqueline Saintenoy-Simon, A.M.B.E, Association pour l'Etude de la Floristique, Bruxelles, Belgium; Hanno Schäfer, author of "Flora of the Azores"; Anna Scoppola, Università Tuscia, Italy; Rubim da Silva, University of Porto, Portugal; Arne Strid, Göteborg Botanical Garden, Sweden; Thomas Raus, Botanischer Garten Berlin, Deutschland; FloraLise Vuille, University of Zürich, Switzerland; Joanna Zalewska, Department of Plant Taxonomy and Phytogeography, Institute of Botany, Jagiellonian University, Poland.

\section{References}

Aronsson M (1999) Rödlistade kärlväxter i Sverige, vol 1. ArtDatabanken SLU, Uppsala

Bini LM, Diniz-Filho JAF, Ranger TFLVB, Bastos RP, Plaza Pinto M (2006) Challenging Wallacean and Linnean shortfalls: knowledge gradients and conservation planning in a biodiversity hotspot. Divers Distrib 12:475-482. doi:10.1111/j.1366-9516.2006.00286.x

Brown JH, Lomolino MV (1998) Biogeography, 2nd edn. Sinauer Press, Sunderland 
Butchart SHM, Stattersfield AJ, Bennun SM, Shutes SM, Akçakaya HR, Baillie JEM, Stuart SN, HiltonTaylor C, Mace GM (2004) Measuring global trends in the status of biodiversity: red list indices for birds. PLoS Biol 2:2294-2304. doi:10.1371/journal.pbio.0020383

Casper SJ, Krausch H-D (1980) Pteridophyta und Anthophyta. In: Ettl H, Gerloff J, Heynig H (eds) Süsswasserflora von Mitteleuropa, Teil 1. Band 23. VEB Gustav Fisher, Jena, pp 169-173

Collar NJ (1998) Extinction by assumption: or, the Romeo Error on Zebu. Oryx 32:239. doi:10.1046/j.13653008.1998.d01-51.x

Cook CDK (1983) Aquatic plants endemic to Europe and the Mediterranean. Bot Jahrb 103:539-582

Cools JMA (1989) Atlas van de Nordbrabantse Flora. Stichting Uitgeverij van de Koninklijke Natuurhistorische Vereniging, Tilburg

Cosson ES-C (1864) Description de deux espèces nouvelles d'Espagne. Bull Soc Bot Fr 11:332-333

Delvosalle L, Vanhecke L (1982) Essai de notion quantitative de la rarefaction d'espèces aquatiques et palustres en Belgique entre 1960 et 1980. In: Symoens JJ, Hooper SS, Compère P (eds) Studies on aquatic vascular plants. Royal Botanical Society of Belgium, Brussels, pp 403-409

Eggenberg S, Landolt E (2006) Für welche Pflanzenarten hat die Schweiz eine internationale Verantwortung? Bot Helv 116:119-133. doi:10.1007/s00035-006-0763-x

Foley JA, DeFries R, Asner GP, Barford C, Bonan G, Carpenter SR, Chapin FS, Coe MT, Daily GC, Gibbs HK, Helkowski JH, Holloway T, Howard EA, Kucharik CJ, Monfreda C, Patz JA, Prentice IC, Ramankutty N, Snyder PK (2005) Global consequences of land use. Science 309:570-573. doi:10.1126/science. 1111772

Glisson B (2004) Saussurea weberi Hulten (Weber's saw-wort): a technical conservation assessment. USDA Forest Service, Rocky Mountain Region. http://www.fs.fed.us. Accessed 11 Oct 2007

Glück H (1905) Biologische und morphologische Untersuchungen über Wasser- und Sumpfgewächse. Erster Teil: Die Lebensgeschichte der europäischen Alismaceen. Gustav Fischer, Jena

Glück H (1906) Alismataceae. In: Kirchner O, Loew E, Schröter C (eds) Lebensgeschichte der Blütenpflanzen Mitteleuropas, Band I, Abteilung I. Eugen Ulmer, Stuttgart, pp 584-648

Good TC, Zjhra ML, Kremen C (2006) Addressing data deficiency in classifying extinction risks: a case study of a radiation of Bignoniaceae from Madagascar. Conserv Biol 20:1099-1110. doi:10.1111/j.15231739.2006.00473.x

Ingelög T, Thor G, Hallingbäck T, Andersson R, Aronsson M (1991) Floravard i jordbrukslandskapet. Skyddsvärda växter, SBT, Lund

IUCN (2001) IUCN Red List categories and criteria: version 3.1. Species Survival Commission, IUCN, Gland. Switzerland and Cambridge, United Kingdom

Jones RA (2006) Creeping water-plantain (Dyfr lyriad ymlusgawl), Baldellia ranunculoides subsp. repens (Lam.) A. Löve \& D. Löve in Wales. In: Leach SJ, Page CN, Peytoureau Y, Sanford MN (eds) Botanical links in the Atlantic arc. BSBI Conference Report No. 24, Camborne, pp 311-319

Kozlowski G (2008) Is the global conservation status assessment of a threatened taxon a utopia? Biodivers Conserv 17:445-448. doi:10.1007/s10531-007-9278-z

Kozlowski G, Jones RA, Nicholls-Vuille F-L (2008) Biological flora of Central Europe: Baldellia ranunculoides (Alismataceae). Perspect Plant Ecol Evol Syst 10:109-142. doi:10.1016/j.ppees.2007.12.003

Lawalrée A (1959) Baldellia repens (Lamk.) van Ooststroom en Belgique. Bull Jard Bot Etat Brux 29:7-14. doi: $10.2307 / 3666990$

Lid J, Lid DT (2005) Norsk flora, 7th edn. Det Norske Samlaget, Oslo

Lindblad R, Ståhl B (1989) Krypfloka (Apium inundatum) och flocksvalting (Baldellia ranunculoides) i norra Halland (SW Sweden). Sven Bot Tidskr 83:211-217

Lindblad R, Ståhl B (1990) Revsvalting, Baldellia repens, i Norden. Sven Bot Tidskr 84:253-258

Lomolino MV, Heaney LR (eds) (2004) Frontiers of biogeography: new directions in the geography of nature. Sinauer Associates, Sunderland

Marris E (2007a) The species and the specious. Nature 446:250-253. doi:10.1038/446250a

Marris E (2007b) What to let go. Nature 450:152-155. doi:10.1038/450152a

Master LL (1991) Assessing threats and seting priorities for conservation. Conserv Biol 5:559-563. doi:10.1111/j.1523-1739.1991.tb00370.x

Moreno Saiz JC, Sainz Ollero H (1992) Atlas corologico de las Monocotiledoneas endemicas de la poninsila Iberica y Baleares. Bases para una politica de conservacion. Colleccion Tecnica, Icona

Mrosovsky N (1997) IUCN's credibility critically endangered. Nature 389:436. doi:10.1038/38873

Mrosovsky N (2004) Predicting extinction: fundamental flaws in IUCN's red list system, exemplified by the case of Sea Turtles. University of Totonto press, Toronto

Pott R (1995) Die Pflanzengesellschaften Deutschlands, 2nd edn. Eugen Ulmer, Stuttgart

Preston CD, Croft JM (2001) Aquatic plants in Britain and Ireland. Harley Books, Colchester 
Quayle JE, Ramsay LR (2005) Conservation status as a biodiversity trend indicator: recommendations from a decade of listing species at risks in British Columbia. Conserv Biol 19:1306-1311. doi:10.1111/j. 1523-1739.2005.00083.x

Rich TCG, Karran AB (2006) Floristic changes in the British Isles: comparison of techniques for assessing changes in frequency of plants in time. Bot J Linn Soc 152:279-302. doi:10.1111/j.1095-8339.2006. 00574.x

Rich TCG, Nicholls-Vuille F-L (2001) Taxonomy and distribution of European Damasonium (Alismataceae). Edinbourg J Bot 58:45-55

Rodrigues ASL (2006) Are global conservation efforts successful? Science 311:1051-1052. doi:10.1126/science. 1131302

Schemske DW, Husband BC, Ruckelshaus MH, Goodwillie C, Parker IM, Bishop JD (1994) Evaluating approaches to the conservation of rare and endangered plants. Ecology 75:584-606. doi:10.2307/1941718

Schubert R, Hilbig W, Klotz S (1995) Bestimmungsbuch der Pflanzengesellschaften Mittel- und Nordostdeutschlands. Gustav Fischer, Stuttgart

Terschuren J (1999) Plan d'action en faveur de Cypripedium calceolus en Europe. Sauvegarde de la Nature: 100. Editions du Conseil de l'Europe

Triest L, Vuille F-L (1991) Isozyme variation in several seed collections and hybrids of Baldellia (Alismataceae). In: Triest L (ed) isozymes in water plants. Opera Bot Belg 4:37-48

Tutin TG (ed) (1980) Flora Europaea. Alismataceae to Orchidaceae, vol 5. Cambridge University Press, Cambridge

Vasconçellos JC (1970) Novas combinaçoes momenclaturais de plantas da flora Portuguesa. Bol Soc Brot Ser 2(44):81-83

Vuille F-L (1988) The reproductive biology of the genus Baldellia (Alismataceae). Plant Syst Evol 159:173-183. doi:10.1007/BF00935970

Welk E (2001) Arealkundliche Analyse und Bewertung der Schutzrelevanz seltener und gefährdeter Gefässpflanzen Deutschlands. PhD Thesis, Martin-Luther-Universität Halle-Wittenberg, Halle/Saale

Whittaker RJ, Araujo MB, Jepson P, Ladle RJ, Watson JEM, Willis KJ (2005) Conservation biogeography: assessment and project. Divers Distrib 11:3-23. doi:10.1111/j.1366-9516.2005.00143.x

Wilcove DS, Chen LY (1998) Management costs for endangered species. Conserv Biol 12:1405-1407. doi: 10.1046/j.1523-1739.1998.97451.x 